(C) В.I. Русин, Я.М. Попович, 2010

удК 616.146-005.6-089.15:612.134

\title{
Роль венозного колектору у виборі показів до хірургічного лікування тромбозів глибоких вен системи нижньої порожнистої вени
}

\author{
B.I. Русин, Я.М. Попович \\ angiosurgery@i.ua
}

Ужггородський начіональний університет, медичний факультет, кафедра хірургічних хвороб, Ужгород

\section{Реферат}

Мета дослідження: визначити покази до хірургічного лікування тромбозів глибоких вен системи нижньої порожнистої вени залежно від стану колатерального та магістрального венозного кровоплину у венозному колекторі.

Матеріали та методи. В роботі проведено аналіз результатів обстеження та лікування 790 пацієнтів із тромбозами глибоких вен системи нижньої порожнистої вени, що знаходилися на лікуванні у Закарпатській обласній клінічній лікарні ім. А. Новака та Закарпатському обласному клінічному онкологічному диспансері з 2006 по 2016 рік. Для обстеження хворих застосували лабораторні методи дослідження, а також інструментальні: ультразвукову доплерографію, ультразвукове дуплексне сканування, рентгеноконтрастну флебографію, мультиспіральну комп'ютерну томографію з внутрішньовенним контрастуванням, радіоізотопну флебосцинтиграфію та ехокардіоскопію. Під час радіоізотопної флебосцинтиграфії у пацієнтів оцінювали функцію м’язово-венозної помпи гомілки в спокої і $з$ навантаженням, визначаючи середній час транспорту, лінійну швидкість кровоплину й індекс навантаження.

Результати досліджень та їх обговорення. Формування тромбу у $89,2 \%$ випадків починається у дрібних м'язових гілках гомілки, що дають початок медіальній групі суральних вен і прогресують знизу вверх, поширюючись на гомілкові та підколінну вену, а далі на стегнові вени і вище. За характером тромботичних мас виділили пухкі, сформовані (організовані) та пухлинні імплантаційні тромби. Пухкі тромботичні маси виявили у 417 (52,8\%) пацієнтів, сформовані - у 344 (43,5\%) та імплантаційні - у 29 (3,7\%) хворих. У більшої частини хворих (408 (73,5\%)) основної групи виявили оклюзійний варіант тромботичного ураження, у $129(23,2 \%)$ хв орих - пристінковий та у $18(3,3 \%)$ - фрагментарний, у тому числі в $403(72,6 \%)$ пацієнтів основної групи проксимальна частина тромботичних мас мала флотуючий характер. У пацієнтів контрольної групи оклюзійний варіант тромботичного ураження виявили у $162(68,9 \%)$, а пристінковий - у 73 (31,1\%) хворих. Флотуючу верхівку тромботичних мас у пацієнтів контрольної групи спостерігали у 34 (14,5\%) випадках.

Наявність фрагментарних тромбів, які втратили точку фіксації, вважали абсолютним показом до операційного лікування. Найбільш небезпечними у плані ТЕЛА вважали також свіжі пухкі тромботичні маси, які не фіксовані до венозної стінки. Сформовані тромби, особливо при їх оклюзійному характері несли меншу небезпеку ТЕЛА. При наявності флотуючої верхівки тромботичних мас оцінювали довжину вільної проксимальної частини тромбу. При протяжності вільної проксимальної частини тромбу до 4 см обирали очікувальну тактику, за винятком булавоподібної форми флотуючої верхівки у $8,7 \%$ пролікованих пацієнтів, яку розцінювали як емболонебезпечну та вважали абсолютним показом до операції.

Наявність пухлинних тромбів, внаслідок відсутності ефекту від антикоагулянтної терапії, вважали прямим показом до операційного лікування. При необхідності резекції стінки НПВ при пухлинному тромбозі, 3 метою попередження стенозування останньої, виконували алопластику (дефект НПВ більше 1/3 окружності) або алопротезування (дефект - більше $2 / 3$ окружності) останньої.

Висновки. При сегментарній тромботичній оклюзії магістралі операційне лікування тромбозів глибоких вен показано лише при наявності флотуючої верхівки. При оклюзії приносної магістралі та венозного колектора перевагу слід надавати тромбектомії, а при наявності флотуючої верхівки покази до операційного лікування стають абсолютними. При ураженні двох венозних колекторів і їх магістралей лише операційне втручання здатне відновити магістральний кровоплин.

Ключові слова: тромбоз глибоких вен, тромбектомія, флотуючий тромб, колатеральний кровоплин, венозний колектор.

The role of the venous collector to the determinate indications of a surgical treatment of deep vein thrombosis of the vena cava inferior system

Rusyn V.I, Popovych Ya. M.

Uzhhorod National University, Faculty of Medicine, Department of Surgical Diseases, Uzhhorod

\section{Abstract}

The aim of research was to determine the indications of a surgical treatment of deep vein thrombosis of the vena cava inferior system depending on the state of the collateral and magistral venous blood flow in the venous collector.

Methods. The analysis is made of results examination and treatment of 790 patients with acute thrombosis in the vena cava inferior system and being treated at departments of angiosurgery and urology of the Transcarpathian Regional Clinical Hospital A. Novak and the surgical department of the Transcarpathian Regional Clinical Oncology Center during 2006 - 2016. For investigation of patients were used the laboratory methods of examination, also the instrumental: ultrasound duplex scanning, X-ray phlebography, computer tomography, radionuclide fleboscintigraphy and ultrasound scanning of heart. During the radionuclide fleboscintigraphy of patients at rest and during physical activity, the function of the muscle-venous pump of the tibial was evaluated: the average transport time, the linear speed of blood flow and the loading index. 
Results of research. $89,2 \%$ of cases the formation of the thrombus begins in the shallow muscle branches of the tibial, giving outset the medial group of the sural veins, and progresses from the bottom upwards, extending to the tibial and popliteal veins, and then to the femoral veins and above. By the nature of thrombotic masses were isolated the loose formed (organized) and the implantation tumor thrombs. $417(52,8 \%)$ of patients revealed the loose thrombotic masses, $344(43,5 \%)$ - the formed ones, and $29(3,7 \%)$ - the implantation tumor thrombs. The most of patients $(408(73,5 \%))$ the main group the occlusive nature of thrombotic lesion were detected, $129(23,2 \%)$ of patients - parietal and $18(3,3 \%)$ - fragmentary, including $403(72.6 \%)$ of patients the main group with the proximal part of thrombotic masses having a floating nature. $162(68,9 \%)$ of patients in control group the occlusive nature of thrombotic lesion was detected, $73(31,1 \%)$ of patients - parietal. $34(14,5 \%)$ of patients in control group a floating top of thrombotic masses was observed.

The presence of fragmentary thrombus, which lost the fixation point, was considered as an absolute indication for the surgical treatment. The fresh, loose thrombotic masses that aren $t$ fixed to venous wall were considered as the most dangerous at pulmonary thromboembolism. The formed thrombus, especially with their occlusive nature, carried the less risk of pulmonary thromboembolism. Having the floating top of thrombotic mass, the length of free proximal thrombus part was estimated. With the length of free proximal thrombus part up to $4 \mathrm{~cm}$, waiting tactics were selected, except the tip-shaped form of floating top in $8,7 \%$ of treated patients, which was considered as embolus and assumed as absolute indication for surgery.

Due to the lack of anticoagulation therapy effect, the presence of tumour thrombus was considered as a direct indication to surgical treatment. If necessary the resection of the wall of vena cava inferior with tumour thrombosis in order to prevent the stenosis the latter, it was performed the aloplasty (defect of the vena cava inferior more than $1 / 3$ of the circle) or aloprothesis (defect more than $2 / 3$ of the circle) of the latter.

Conclusions. At the segmental thrombotic occlusion of the main magistral the surgical treatment of the deep vein thrombosis showed only at the presence a floating top. At occlusion of the abduction magistral and venous collector the preference be given to thrombectomy. And at the presence of the floating top, the indications for surgical treatment become absolute. At affected of two venous colectors and their magistrals only the surgical intervention is able to restore the main magistral blood flow.

Key words: deep vein thrombosis, thrombectomy, floating thrombus, collateral blood flow, venous collector.

Вступ. На даний час опубліковані численні рекомендації, що узагальнюють досвід, і оригінальні авторські статті на позиціях доказової медицини, які присвячені питанням діагностики, факторам ризику, вибору методів лікування пацієнтів із тромбозами глибоких вен (ТГВ) і тромбоемболії легеневої артерії (ТЕЛА) [6, 7]. Досягнення поставлених завдань можливо шляхом антикоагулянтної терапії, тромболізису або операційного втручання (тромбектомія, перев'язка магістральних вен, плікація нижньої порожнистої вени (НПВ), ендоваскулярні втручання) [5]. Але, незважаючи на широкий діапазон антикоагулянтних засобів - адекватне консервативне лікування при ТГВ отримують, за різними даними, від $1-5 \%$ до $25-58,8 \%$ пацієнтів $[1,3]$. В той же час, широкий перелік протипоказів, часті геморагічні ускладнення, важкий підбір оптимальної дози тромболітика, тривалості його застосування, необхідність імплантації кава-фільтра (КФ) внаслідок небезпеки фрагментації тромбу, часті випадки неефективного тромболізису призвели до обмеженого використання даного методу лікування венозних тромбоемболічних ускладнень (ВТЕУ) [2, 8, 9].

Частота хірургічного лікування ТГВ, незважаючи на постійне зростання частоти ТЕЛА, залишається низькою, так частота тромбектомій 3 магістральних вен сягає лише 20-25\% [3, 4], що пов'язано головним чином 3 кваліфікацією лікаря та традиціями клініки [2].

Не переконують авторів у неефективності антикоагулянтної терапії навіть результати консервативного лікування ТГВ: через 5 років у 95\% пацієнтів спостерігають венозну гіпертензію, у $90 \%$ - виражений венозний рефлюкс, у 50\% порушення функції м'язово-венозної помпи гомілки, у 15\% - трофічні виразки та у $15-50 \%-$ переміжну венозну кульгавість $[11,12]$. Хоча B. Geier і співавтори (2009) наводять дані про збереження прохідності реканалізованих ділянок глибоких вен через 5 років після відкритої тромбектомії у 75\% пацієнтів та наявність ознак посттромбофлебітичного синдрому (ПТФС) лише у $20 \%$ випадків [10].

Таким чином, лікування тромбозів у системі НПВ досі не стандартизовано, відсутній єдиний погляд як на різні схеми консервативної терапії (терапія низькомолекулярними гепаринами, системний і регіонарний тромболізис), так і на численні хірургічні методи лікування (плікація НПВ, тромбектомія на тлі прискореного кровотоку або без нього, імплантація кава-фільтрів та ін.) Показання та протипоказання до них часто суперечать один одному. Це спонукає до спроб стандартизувати лікування даної патології, зменшення кількості ВТЕУ і поліпшення якості життя пацієнтів.

Мета дослідження. Покращити результати лікування хворих на тромбози глибоких вен системи нижньої порожнистої вени шляхом обгрунтуванням методики хірургічної тромбектомії для профілактики тромбоемболії легеневої артерії в залежності від кількості та рівня ураження венозного колектора та виду тромбу.

Матеріали та методи дослідження. У роботі проведено аналіз результатів обстеження та лікування 790 пацієнтів із ТГВ системи НПВ, що 
знаходилися на лікуванні у Закарпатській обласній клінічній лікарні ім. А. Новака та Закарпатському обласному клінічному онкологічному диспансері з 2006 по 2016 рік. Залежно від проведеного лікування пацієнти були поділені таким чином: І група - 555 хворих, яким проводили операційне лікування 3 наступним консервативним лікуванням, та II група - 235 пацієнтів, яким призначали лише консервативну антикоагулянтну терапію. I групу залежно від хірургічного способу лікування поділили на такі підгрупи: I A - 380 пацієнтів, яким виконували повну або парціальну тромбектомію 3 наступною хірургічною профілактикою ТЕЛА або без неї; І Б 50 хворих, яким виконували комбіноване лікування 3 наступною хірургічною профілактикою ТЕЛА; І В - 125 пацієнтів, яких оперували 3 приводу трансфасціального тромбозу.

Вік хворих коливався у широких межах від 17 до 83 років, середній вік - 46 22,3 року. Серед них чоловіків було 334 (42,3\%), а жінок - 456 (57,7\%). Переважна кількість пролікованих пацієнтів були працездатного віку - 735 (93,0\%) осіб. При цьому половину всіх обстежених та пролікованих хворих склали особи молодого та середнього віку (до 40 років) - 395 (50\%).

Для обстеження хворих застосували лабораторні методи дослідження, а також інструментальні: ультразвукову доплерографію, ультразвукове дуплексне сканування («ULTIMA PRO-30, z.one Ultra», ZONARE Medical Systems Inc., СШA); рентгеноконтрастну флебографію (DSA, Integris-2000, Philips), мультиспіральну комп'ютерну томографію з внутрішньовенним контрастуванням (Somatom CRX «Siemens», Німеччина, 1994) та ехокардіоскопію. Також проводили радіоізотопну флебо- сцинтиграфію на емісійному комп'ютерному томографі «Тамара» (ГКС-301Т) виробництва ГПФ СКТБ «Оризон» Україна, НИО ЩГК НТК «Інститут монокристалів» НАН України, СП «АмкрисЭйч». Під час радіоізотопної флебосцинтиграфії визначали середній час транспорту (СЧТ) ізотопу та індекс навантаження (IH).

Результати досліджень та їх обговорення. Для практичних цілей ми розділили венозну систему нижніх кінцівок на 4 сегменти: гомілковопідколінний (м'язово-венозна помпа гомілки), підколінно-стегновий, стегново-клубовий і клубово-кавальний венозні сегменти. Під терміном венозний сегмент розуміємо сукупність усіх судин, що здійснюють доцентровий кровоплин. При цьому функціональна активність сегмента це сумарна пропускна спроможність всіх його складових. Компетентність венозного сегмента визначається можливістю забезпечення фізіологічно необхідного відтоку з дистальних відділів кінцівки.

Уявлення про будову венозного сегмента виглядає таким чином. У формуванні кожного 3 них беруть участь: «приносні магістралі» (глибокі вени гомілки, проксимальний відділ підколінної (ПВ), поверхнева стегнова (ПСВ), зовнішня клубова (ЗоКВ), нижня порожниста вени), венозні колектори (їх $€$ чотири: підколінний, стегновий, клубовий і кавальний) i їх шунти (мала (МПВ) і велика (ВПВ) підшкірні, глибока стегнова (ГСВ), статеві, внутрішні клубові, хребетні, висхідна поперекова вени), а також «виносні магістралі» (ПСВ, ЗоКВ, НПВ). Одна і та ж магістраль може бути приносною для одного i виносною для іншого сегмента (рис. 1).

\section{Схема будови венозного сегменту}

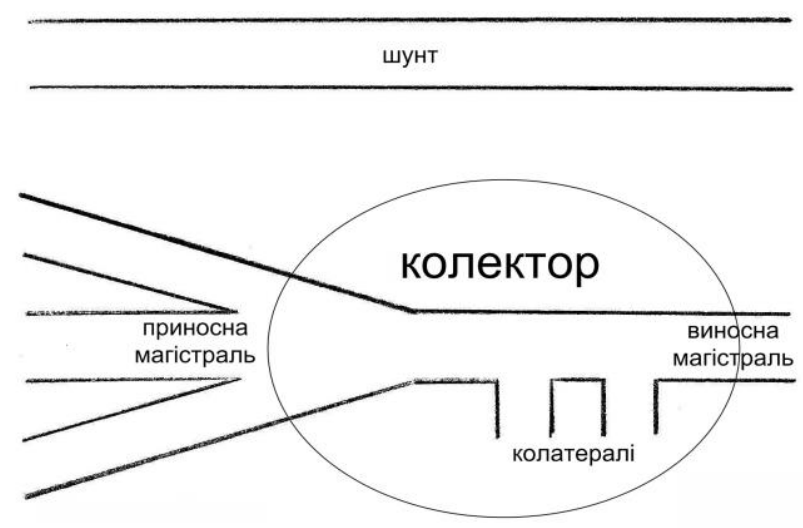

Рис. 1. Схема будови венозного колектора.

Запропонований принцип будови венозного сегмента відповідає загальним уявленням про функціональну анатомію венозного русла. Найбільше значення в порушенні відтоку має венозний колектор. У колектор завжди впадають декілька приносних вен, а виходить одна виносна, яка є приносною для вищерозміщеного сегмента. 
Кожен колектор має обхідний шлях - природний шунт, від функціональної можливості якого залежить ступінь порушення відтоку при оклюзії колектора. Для підколінного - це ВПВ, ГСВ і колатералі - мережа колінного суглоба, а також вена Джакоміні; для стегнового сегмента - це стегнові вени і крижове сплетення; для клубового - внутрішня клубова вена (ВнКВ) i вени передньої черевної стінки; для клубового - непарна та напівнепарна вени, поперекові вени та їх венозні сплетення, міжхребцеві та нижні діафрагмальні вени, печінкові вени, гонадні вени, венозні сплетення малого тазу та гілки ВнКВ.

Виходом із колектора завжди є магістраль, яка не має великої кількості приток, зокрема: ПСВ, загальна стегнова вена (ЗСВ), загальна клубова вена (ЗКВ) і НПВ. Найменший вплив на кровоплин має оклюзія ПВ і ПСВ (наявні шунти здатні повністю компенсувати його непрохідність). Головним шунтом є ВПВ, яка здатна в умовах оклюзії глибоких вен майже повністю взяти на себе «фізіологічну» норму глибокої венозної системи. Крім того, велике значення в компенсації кровоплину мають глибока і огинаюча стегнову кістку вени. Основні шунти - ВПВ і ГСВ здатні взяти на себе функцію і колектора, і виносної магістралі. На цьому етапі захворювання неспроможність комунікантів відіграє позитивну роль. Кровоплин цілком компенсований і немає необхідності його покращувати.

Значної уваги ми надавали визначенню варіанта тромботичного ураження та характеру тромботичних мас. Так, у більшої частини хворих $(408(73,5 \%))$ основної групи виявили оклюзійний варіант тромботичного ураження, у 129 $(23,2 \%)$ хворих - пристінковий та у $18(3,3 \%)-$ фрагментарний, у тому числі у 403 (72,6\%) пацієнтів основної групи проксимальна частина тромботичних мас мала флотуючий характер. У пацієнтів контрольної групи оклюзійний варіант тромботичного ураження виявили у 162 (68,9\%), а пристінковий - у 73 (31,1\%) хворих. Флотуючу верхівку тромботичних мас у пацієнтів контрольної групи спостерігали у 34 (14,5\%) випадках. Пацієнтів із фрагментарним варіантом тромботичного ураження в контрольну групу не включали.

За характером тромботичних мас виділили пухкі, сформовані (організовані) та пухлинні імплантаційні тромби. Пухкі тромботичні маси виявили у 417 (52,8\%) пацієнтів, сформовані - у $344(43,5 \%)$ та імплантаційні - у 29 (3,7\%) хворих. У пацієнтів основної групи найчастіше виявляли пухкі тромботичні маси - у 380 (68,5\%), сформовані - у 146 (26,3\%) та пухлинні - у 29
$(5,2 \%)$ хворих. У контрольній групі у переважній більшості пацієнтів - 198 (84,3\%) спостережень - виявили сформовані тромботичні маси. Пухкий характер тромботичних мас виявили у 37 (15,7\%) хворих. Пацієнтів 3 імплантаційним тромбозом у контрольну групу не включали, оскільки останні взагалі не піддаються антикоагулянтній терапії.

Встановлено, що формування тромбу у 89,2\% випадків починається у дрібних м'язових гілках гомілки, що дають початок медіальній групі суральних вен і прогресують знизу вверх, поширюючись на гомілкові та підколінну вену, а далі на стегнові вени і вище.

Під час дослідження регіонарної гемодинаміки визначали середній час транспорту (СЧТ) радіофармпрепарату (РФП) під час радіоізотопної флебосцинтиграфії (РФСГ), лінійну швидкість кровоплину (ЛШК). Для об'єктивізації оцінки, ми ввели відносну величину - індекс навантаження (IH), тобто відношення СЧТ при навантаженні до цього ж показника в спокої. У нормі ІН складає - від 3 одиниць і вище.

Встановлено, що СЧТ РФП по венах гомілки та стегна при ТГВ зростає в середньому до $59,4 \pm 4,02$ с $(\mathrm{p} \leq 0,01)$ в спокої та 28,6 $\pm 3,97$ с $(\mathrm{p} \leq 0,01)$ при фізичному навантаженні (при нормі до 15 - 20 с в спокої та до 8-12 с при фізичному навантаженні). ЛШК при ТГВ знижується в середньому до $2,1 \pm 0,61 \mathrm{~cm} / \mathrm{c}(\mathrm{p} \leq 0,05)$ у спокої та до $3,8 \pm 0,84 \mathrm{~cm} / \mathrm{c}(\mathrm{p} \leq 0,05)$ при фізичному навантаженні (при нормі 5-8 см/с в спокої та 6$14 \mathrm{~cm} / \mathrm{c}$ при фізичному навантаженні). IН при ТГВ складає в середньому $1,6 \pm 0,49$ од. при нормі 3 од. і вище.

При тромботичній оклюзії НПВ дистальніше

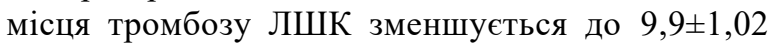
$\mathrm{cm} / \mathrm{c} \quad(\mathrm{p} \leq 0,05)$, пульсовий тиск зростає до $54,6 \pm 2,63$ мм рт. ст. $(\mathrm{p} \leq 0,01)$, а тиск у НПВ досягає $8,35 \pm 0,99$ мм рт. ст. $(\mathrm{p} \leq 0,001)$. Вище місця тромботичної оклюзії кровоплин прискорюється ЛШК підвищується до $15,1 \pm 1,49$ см/с $(\mathrm{p} \leq 0,05)$, рівень пульсового тиску та тиску в НПВ знижуються до $45,4 \pm 1,85$ мм рт. ст. $(\mathrm{p} \leq 0,01)$ та $6,73 \pm 1,06$ мм рт. ст. $(\mathrm{p} \leq 0,001)$ відповідно.

СЧТ РФП у НПВ при іiі тромбозі зростає в середньому до $43,6 \pm 2,2$ с $(\mathrm{p} \leq 0,05)$ в спокої та $24,0 \pm 1,8$ c $(\mathrm{p} \leq 0,05)$ при фізичному навантаженні, ЛШК знижується в середньому до 4,3 $\pm 0,07 \mathrm{~cm} / \mathrm{c}$ $(\mathrm{p} \leq 0,01)$ у спокої та до $6,0 \pm 0,07 \mathrm{~cm} / \mathrm{c} \quad(\mathrm{p} \leq 0,01)$ при фізичному навантаженні, а IH складає у середньому $1,43 \pm 0,5$ од.

Операційні втручання, спрямовані на лікування ТГВ та профілактику ТЕЛА, у вищезгаданих пацієнтів представлені в таблицях 1-3. 
Операційні втручання при тромбозі глибоких вен у пацієнтів I А групи

\begin{tabular}{|l|c|}
\hline \multicolumn{1}{|c|}{ Вид операційного втручання } & Кількість \\
\hline $\begin{array}{l}\text { Тромбоектомія із ПВ і литкових пазух, лігування литкових пазух у } \\
\text { місці впадіння в ПВ }\end{array}$ & $70(18,4 \%)$ \\
\hline $\begin{array}{l}\text { Тромбоектомія із ПВ, лігування тромбованих стовбурів гомілкових вен } \\
\text { у місці впадіння в ПВ }\end{array}$ & $35(9,2 \%)$ \\
\hline Тромбектомія із ПСВ, лігування ПСВ нижче впадіння ГСВ & $67(17,6 \%)$ \\
\hline Тромбектомія із ЗСВ, лігування ПСВ нижче впадіння ГСВ & $55(14,5 \%)$ \\
\hline Тромбектомія із ЗСВ, лігування ГСВ у місці впадіння у ЗСВ & $21(5,5 \%)$ \\
\hline Тромбектомія із ЗСВ і ЗоКВ, лігування ПСВ нижче впадіння ГСВ & $58(15,3 \%)$ \\
\hline Тромбектомія із ЗСВ і ЗоКВ, лігування ЗСВ нижче впадіння ВПВ & $3(0,8 \%)$ \\
\hline Тромбектомія із ЗСВ і ЗоКВ з формуванням дистальної АВФ & $13(3,4 \%)$ \\
\hline Тромбектомія із ЗоКВ І ЗКВ, лігування ЗоКВ нижче впадіння ВнКВ & $7(1,8 \%)$ \\
\hline Тромбектомія з інфра- і/або інтраренального відділу НПВ & $11(2,9 \%)$ \\
\hline $\begin{array}{l}\text { Тромбектомія з інфра- і/або інтраренального відділу НПВ + апаратна } \\
\text { каваплікація НПВ }\end{array}$ & $5(1,3 \%)$ \\
\hline Тромбектомія з супраренального відділу НПВ & $9(2,4 \%)$ \\
\hline $\begin{array}{l}\text { Тромбектомія з супраренального відділу НПВ + апаратна каваплікація } \\
\text { НПВ }\end{array}$ & $12(3,2 \%)$ \\
\hline $\begin{array}{l}\text { Тромбектомія з піддіафрагмального відділу НПВ та правого передсер- } \\
\text { дя }\end{array}$ & $1(0,3 \%)$ \\
\hline $\begin{array}{l}\text { Тромбектомія з піддіафрагмального відділу НПВ і правого передсердя } \\
+ \text { апаратна каваплікація НПВ }\end{array}$ & $13(3,4 \%)$ \\
\hline Всього & $380(100 \%)$ \\
\hline
\end{tabular}

Таблиця 2

Комбіноване лікування пацієнтів I Б групи

\begin{tabular}{|c|c|c|c|c|c|c|c|c|c|c|c|}
\hline \multicolumn{2}{|c|}{ Комбіноване } & \multicolumn{2}{|c|}{$\begin{array}{c}\text { Гоміл- } \\
\text { кові } \\
\text { вени }\end{array}$} & \multicolumn{2}{|c|}{$\begin{array}{c}\text { Підколінна } \\
\text { вена }\end{array}$} & \multicolumn{2}{|c|}{$\begin{array}{c}\text { Стегнові } \\
\text { вени }\end{array}$} & \multicolumn{2}{|c|}{$\begin{array}{l}\text { Клубові } \\
\text { вени }\end{array}$} & \multicolumn{2}{|c|}{ Всього } \\
\hline \multirow[t]{2}{*}{$\begin{array}{l}\text { Регіонарна тром- } \\
\text { болітична терапія }\end{array}$} & $\begin{array}{l}\text { Імплантація кава- } \\
\text { фільтра }\end{array}$ & 3 & \multirow[t]{2}{*}{7} & 2 & \multirow[t]{2}{*}{5} & 7 & \multirow[t]{2}{*}{19} & 19 & \multirow[t]{2}{*}{19} & 31 & \multirow[t]{2}{*}{50} \\
\hline & $\begin{array}{l}\text { Хірургічна тром- } \\
\text { бектомія }\end{array}$ & 4 & & 3 & & 12 & & - & & 19 & \\
\hline
\end{tabular}

Наявність фрагментарних тромбів, які втратили точку фіксації, вважали абсолютним показом до операційного лікування. Найбільш небезпечними у плані ТЕЛА вважали також свіжі пухкі тромботичні маси, які не фіксовані до венозної стінки. Сформовані тромби, особливо при їх оклюзійному характері несли меншу небезпеку ТЕЛА. При наявності флотуючої верхівки тромботичних мас оцінювали довжину вільної проксимальної частини тромбу. При протяжності вільної проксимальної частини тромбу до 4 см обирали очікувальну тактику, за винятком булавоподібної форми флотуючої верхівки у 8,7\% пролікованих пацієнтів, яку розцінювали як емболонебезпечну та вважали абсолютним показом до операції.

Наявність флотуючої верхівки при трансфасціальному тромбозі вважали абсолютним пока- зом до операційного лікування, яке передбачало не лише тромбектомію із глибокої венозної системи, а й наступне видалення тромботично уражених поверхневих вен.

При сегментарній тромботичній оклюзії магістралі без ураження венозного колектора і колатералей операційне втручання виконували лише при наявності емболонебезпечного флотуючого тромбу. При поширенні тромбозу з приносної магістралі на венозний колектор та виключенні 3 кровоплину основних колатералей, які впадають в уражений колектор, перевагу надавали операційному лікуванню. А при тромботичній оклюзії двох венозних колекторів із магістралями й колатералями та/або наявності флотуючої проксимальної частини тромбу покази до операційного лікування вважали абсолютними. 
Операційні втручання, які виконані у пацієнтів I В групи

\begin{tabular}{|l|c|}
\hline \multicolumn{1}{|c|}{ Оперативне втручання } & Кількість \\
\hline Напіввідкрита тромбектомія з ЗСВ, кросектомія, флебектомія & $54(43,2 \%)$ \\
\hline $\begin{array}{l}\text { Відкрита тромбектомія з ЗСВ (з венотомією ЗСВ), кросектомія, флебек- } \\
\text { томія }\end{array}$ & $8(6,4 \%)$ \\
\hline $\begin{array}{l}\text { Напіввідкрита тромбектомія із ПВ, кросектомія, флебектомія МПВ та /або } \\
\text { ВПВ }\end{array}$ & $15(12,0 \%)$ \\
\hline $\begin{array}{l}\text { Відкрита тромбектомія з ПВ (із венотомією ПВ), кросектомія, флебектомія } \\
\text { ВПВ та МПВ }\end{array}$ & $5(4,0 \%)$ \\
\hline $\begin{array}{l}\text { Відкрита тромбектомія з ПВ (із венотомією ПВ) та/або суральних синусів, } \\
\text { кросектомія, флебектомія ВПВ і МПВ, лігування тромбованих суральних } \\
\text { синусів }\end{array}$ & $26(20,8 \%)$ \\
\hline Лігування ПСВ нижче впадіння ГСВ, кросектомія, флебектомія & $3(2,4 \%)$ \\
\hline Кросектомія, флебектомія ВПВ, лігування ПВ нижче впадіння МПВ & $7(5,6 \%)$ \\
\hline Відкрита тромбектомія з пронизних вен, кросектомія, флебектомія & $7(5,6 \%)$ \\
\hline Всього & $125(100 \%)$ \\
\hline
\end{tabular}

Примітка: ВПВ - велика підшкірна вена, МПВ - мала підшкірна вена.

Наявність пухлинних тромбів внаслідок відсутності ефекту від антикоагулянтної терапії вважали прямим показом до операційного лікування. При необхідності резекції стінки НПВ при пухлинному тромбозі, 3 метою попередження стенозування останньої, виконували алопластику (дефект НПВ більше $1 / 3$ окружності) або алопротезування (дефект - більше $2 / 3$ окружності) останньої.

У 91,1\% пацієнтів I А групи хірургічне лікування ТГВ поєднували з операційним втручанням, спрямованим на профілактику ТЕЛА (лігування та плікація). При цьому у 58,8\% пацієнтів 3 тромбозом НПВ внаслідок протяжних або фіксованих тромбів НПВ та масивного низхідного тромбозу клубових вен операцію завершували неповною апаратною каваплікацією.

У 16,0\% пацієнтів після тромбектомій із загальної стегнової вени (ЗСВ) і ЗоКВ, із метою зменшення частоти післяопераційних ретромбозів і покращення результатів тромбектомії, втручання завершували формуванням артеріовенозної фістули (АВФ) діаметром до 4 мм по типу «кінець вен у бік артерії».

У $31,4 \%$ пацієнтів із тромбозами НПВ тромботичні маси не поширювалися вище ниркових вен, у 68,6\% хворих тромботичні рани поширювалися вище ниркових вен, в тому числі у 9,8\% хворих процес локалізувався вище діафрагми.

При довжині флотуючого тромбу більше 3 см або його частковій фіксації, з метою адекватної тромбектомії при трансфасціальному тромбозі, виконували венотомію ЗСВ або ПВ.

При виконанні регіонарної тромболітичної терапії використовували поєднання декількох методів введення тромболітика, із метою досягнення найкращого результату та зменшення дози введеного препарату. Тромболітичну терапію поєднали $з$ ендоваскулярною імплантацією кавафільтра $(\mathrm{n}=31)$ та відкритою тромбектомією (n=19). Після тромбектомії інтраопераційно проводили регіонарну інфузію тромболітичного препарату в дистальне венозне русло. При цьому тромболітичну терапію найчастіше проводили під час тромбектомії зі стегнових вен - у 63,2\% пацієнтів.

При оцінці венозного кровоплину залежно від способу хірургічного лікування ТГВ встановлено ефективність хірургічного втручання. Так, СЧТ по глибоких венах гомілки та стегна зменшився 3

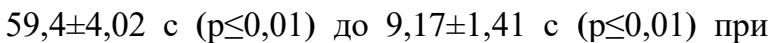
радикальній i до $13,83 \pm 1,95$ с $\quad(\mathrm{p} \leq 0,01) \quad$ при парціальній тромбектомії. ЛШК зростала 3 $2,1 \pm 0,61 \mathrm{~cm} / \mathrm{c}(\mathrm{p} \leq 0,05)$ до $13,27 \pm 2,36 \mathrm{~cm} / \mathrm{c} \quad(\mathrm{p} \leq 0,05)$ та до $6,73 \pm 1,47 \mathrm{~cm} / \mathrm{c}(\mathrm{p} \leq 0,05)$ при радикальній та парціальній тромбектоміях відповідно. IН зріс із $1,6 \pm 0,49$ од. $(\mathrm{p} \leq 0,05)$ до $3,35 \pm 0,46$ од. $(\mathrm{p} \leq 0,05)$ та $2,58 \pm 0,32$ од. $(\mathrm{p} \leq 0,05)$ при радикальній та парціальній тромбектоміях відповідно.

У II групі пацієнтів СЧТ після лікування склав $27,63 \pm 2,78$ с $(p \leq 0,01)$, а ЛШК та IH $3,68 \pm 1,15 \mathrm{~cm} / \mathrm{c}(\mathrm{p} \leq 0,05)$ та $1,75 \pm 0,27$ од. $(\mathrm{p} \leq 0,05)$ відповідно. Результати відновлення кровоплину після комбінованого лікування у пацієнтів I Б групи зайняли проміжне становище між радикальною та парціальною тромбектомією: СЧТ $11,38 \pm 1,28$ с $(\mathrm{p} \leq 0,01)$, ЛШК $-8,82 \pm 1,21 \mathrm{~cm} / \mathrm{c}$ $(\mathrm{p} \leq 0,05)$ та IH $-3,02 \pm 0,29$ од. $(\mathrm{p} \leq 0,05)$.

У віддаленому періоді у пацієнтів I А групи після повної тромбектомії у жодного пацієнта не спостерігали ознак хронічної венозної недостатності (ХВН), а після парціальної тромбектомії у 9,2\% хворих. Ознаки хронічної венозної недостатності (XBH) упродовж 3 років спостереження виявили у $27,3 \%$ та $5,9 \%$ хворих I Б та I В груп відповідно. При цьому у хворих II групи клінічні прояви ХВН у віддаленому періоді спостерігали у 51,0\% випадків.

Добрий та задовільний результат після тромбектомій при ТГВ нижніх кінцівок протягом 
3 років спостереження, за даними кумуляційного аналізу, спостерігали у 89,3\% пацієнтів. Ретромбоз у віддаленому періоді виявлено у 3,4\% хворих. При цьому, жодного випадку ТЕЛА не спостерігали.

Після накладання АВФ, за методикою, запропонованою у клініці, у жодного пацієнта не виявили ознак «периферичного обкрадання», перевантаження правих відділів серця та рецидиву тромбозу. Всі АВФ закрилися самостійно протягом 3-10 тижнів після операції.

Упродовж 1 року після плікації НПВ показники центральної та периферичної гемодинаміки знаходилися у межах фізіологічної норми, а колатеральні шляхи під час РСФГ не визначалися. При цьому, просвіт НПВ повністю відновлювався, через 12-18 місяців, у всіх випадках після плікації.

Добрий та задовільний результат комбінованого лікування ТГВ нижніх кінцівок протягом 3 років спостереження, за даними кумуляційного аналізу, простежувався у 87,1\% пацієнтів. Летальні випадки у цій групі пацієнтів були пов'язані з фатальною ТЕЛА внаслідок проксимальної міграції кава-фільтра.

Добрий та задовільний результат хірургічного лікування трансфасціального тромбозу, за даними кумуляційного аналізу, спостерігали у 88,4\% пацієнтів. Жодного випадку ТЕЛА не виявлено.

Добрий та задовільний результат консерватиного лікування ТГВ нижніх кінцівок протягом 3 років спостереження, за даними кумуляційного аналізу, простежували у 35,3\% пацієнтів. При цьому у 22,6\% хворих з ознаками ХВН спостерігали трофічні виразки.

При кількісній оцінці результатів лікування ТГВ та оцінці якості життя у всіх без винятку параметрах показники у пацієнтів основної групи були значно вищі від хворих контрольної групи.

Залежно від захоплення в тромботичний процес анатомічних структур венозного колектора ми виділили такі покази до хірургічного лікування (таблиця 4).

Вибір методу хірургічного лікування тромбозів глибоких вен у системі нижньої порожнистої вени залежно від локалізації тромботичного ураження

\begin{tabular}{|c|c|c|c|c|}
\hline \multirow{2}{*}{\multicolumn{2}{|c|}{ Сегмент НПВ }} & Межі тромбот & го ураження & \multirow[b]{2}{*}{ Вид лікування } \\
\hline & & $\begin{array}{l}\text { Магістраль } \\
(+/-)\end{array}$ & $\begin{array}{l}\text { Колектор } \\
(+/-)\end{array}$ & \\
\hline \multirow{2}{*}{\multicolumn{2}{|c|}{ Гомілково-підколінний }} & + & - & $\begin{array}{c}\text { медикаментозне / лігування } \\
\text { тромбованої судини }\end{array}$ \\
\hline & & + & + & тромболізис \\
\hline \multirow{2}{*}{\multicolumn{2}{|c|}{ Підколінно-стегновий }} & + & - & медикаментозне / лігування \\
\hline & & + & + & тромболізис \\
\hline \multirow{2}{*}{\multicolumn{2}{|c|}{ Стегново-клубовий }} & + & - & тромбектомія \\
\hline & & + & + & тромбектомія + АВФ* \\
\hline \multirow{2}{*}{\multicolumn{2}{|c|}{ Клубово-кавальний }} & + & - & тромбектомія + АВФ* \\
\hline & & + & + & каваплікація \\
\hline \multirow{6}{*}{ Кавальний } & \multirow{2}{*}{ інфраренальний } & + & - & тромбектомія \\
\hline & & + & + & тромбектомія \\
\hline & \multirow{2}{*}{ інтраренальний } & + & - & тромбектомія \\
\hline & & + & + & тромбектомія + каваплікація \\
\hline & \multirow[b]{2}{*}{ супраренальний } & + & - & тромбектомія + каваплікація \\
\hline & & + & + & $\begin{array}{c}\text { тромбектомія з ниркових вен і } \\
\text { НПВ + каваплікація }\end{array}$ \\
\hline \multirow{2}{*}{\multicolumn{2}{|c|}{ Піддіафрагмальний }} & + & - & $\begin{array}{c}\text { тромбектомія з НПВ / ниркових } \\
\text { вен + каваплікація }\end{array}$ \\
\hline & & + & + & $\begin{array}{c}\text { тромбектомія з НПВ / печін- } \\
\text { кових вен / передсердя }\end{array}$ \\
\hline
\end{tabular}

*АВФ - артеріовенозна нориця.

Покращити параметри венозного відтоку не тільки в спокої, а й при фізичному навантаженні, можна лише включивши в кровоплин весь колектор, а не лише одну магістраль. Результатом такого лікування $є$ толерантність пацієнта до фізичного навантаження, яку виражає IH (адекватність відтоку при фізичному навантаженні).

Таким чином, при порівнянні результатів лікування основної та контрольної груп виявили значне покращення стану пацієнтів основної групи за всіма параметрами. Отримані ранні та віддалені результати переконливо демонструють високу ефективність і доцільність застосування операційного лікування тромбозів глибоких вен порівняно $з$ ізольованим консервативним лікуванням. Крім того, відновлення просвіту глибоких вен операційним шляхом дозволяє зберегти клапанний апарат вен, попередити розвиток пост- 
тромбофлебітичного синдрому 3 наступним виникненням хронічної венозної недостатності, значно покращити результати лікування пацієнтів із тромбозами глибоких вен. Крім того, операційні методи лікування тромбозів глибоких вен нижніх кінцівок ефективно попереджують тромбоемболію легеневої артерії.

Висновки: 1. При сегментарній тромботичній оклюзії магістралі, без ураження венозного колектора та колатералей, операційне лікування тромбозів глибоких вен показано лише при наявності флотуючої верхівки, яка трапляється у 64,6\% пацієнтів. При оклюзії приносної магістралі та венозного колектора перевагу слід надавати тромбектомії, а при наявності флотуючої верхівки покази до операційного лікування стають абсолют- ними. При ураженні двох венозних колекторів і їх магістралей лише операційне втручання здатне відновити магістральний кровоплин.

2. Після консервативного лікування тромбозів глибоких вен ознаки хронічної венозної недостатності виявили у 51,0\% випадків, комбінованого лікування - у 27,3\%, парціальної тромбектомії - у 9,2\%, хірургічного лікування трансфасціального тромбозу - у 5,9\% пацієнтів і були відсутні повністю після радикальної тромбектомії.

3. Кумуляційний аналіз виявив добрі та задовільні результати протягом 3 років спостереження при тромбектоміях у 89,3\% пацієнтів, комбінованому лікуванні - у 87,1\%, хірургічному лікуванні трансфасціального тромбозу - у 88,4\% та у 35,3\% після консервативного лікування.

\section{Список використаної літератури}

1. Березницкий Я.С. Оптимизация профилактики тромбоэмболических послеоперационных осложнений. Возможности и реальность / Я.С. Березницкий, Е.Н. Клигуненко, С.Н. Курыляк. Хірургія України. 2008. № 2 (26). С. 57-62.

2. Гудз I.M. Діагностика та лікування гострого тромбозу глибоких вен нижніх кінцівок і тазу. Рекомендації Товариства судинних хірургів Німеччини / І.М. Гудз. Серце і судини. 2006. № 2 (14). С. 3436.

3. Лікування флеботромбозів системи нижньої порожнистої вени, ускладнених флотацією верхівки тромбу / І.І. Кобза, Б.М. Гаврилів, Ю.Г. Орел [та ін.]. Наук. вісник Ужгородського університету, серія «Медицина». Випуск 2 (44). 2012. С. 52-53.

4. Скупий О.М. Комбіновані методи лікування тромбозів глибоких вен системи нижньої порожнистої вени. О.М. Скупий, О.І. Мітюк, Я.В. Хребтій. Наук. вісник Ужгородського університету, серія «Медицина». Випуск 28. 2006. С. 152-154.

5. Сосудистая хирургия. Национальное руководство. Краткое идание / под. ред. В.С. Савельева, А.И. Кириенко. Мосвка: ГЭОТАР-Медиа, 2014. 464 с.

6. «MOPETT» Investigators. Moderate pulmonary embolism treated with thrombolysis (from the 'MOPETT' Trial) / M. Sharii, C. Bay, L. Skrocki [et al.]. Am. J. Cardiol. 2013. № 111. P. 273-277.

7. Derivation and Validation of Multimarker Prognostication for Normotensive Patients with Acute Symp tomatic Pulmonary Embolism / D. Jiménez, D. Kopecna, V. Tapson [et al.]. Am. J. of Respir. and Crit. Care Med. 2014. № 189 (6). P. 718-726.

8. Fixed low-dose ultrasound-fssisted catheter-directed thrombolysis followed by routine stenting of residual stenosis for acute ilio-femoral deep-vein thrombosis / R.P. Engelberger, J. Fahrni, T. Willenberg [et al.]. Thromb. Haemost. 2014. № 1. P. 111-116.

9. Lippi G. Novel and emerging therapies: thrombus-targeted fibrinolysis / G. Lippi, C. Mattiuzzi, E.J. Favaloro. Semin. Thromb. Hemost. 2012. Vol. 39. P. 48-58.

10. Long-term Results after Transfemoral Venous Thrombectomy for Iliofemoral Deep Venous Thrombosis / B. Geier, G. Asciutto, B. Strohmann [et al.]. Abstracts XXIII Annual Meeting European Society for Vascular Surgery (3-6 September 2009, Oslo, Norway). P. 148.

11. Rosales A. Stenting for Chronic Postthrombotic Cava and Iliofemoral Occlusions. Clinical Ou tcome and Midterm Patency / A. Rosales, G. Sanbæk, J.J. Jørgensen. Abstracts XXIII Annual Meeting European Society for Vascular Surgery (3-6 September 2009, Oslo, Norway). P. 59.

12. The Vein Book: monograph / Edited by:John J. Bergan. London-Oxford: Elsevier Academic Press. 2007. 617 p.

\section{Стаття надійшла до редакції: 6.11.2019 р.}

